\title{
Impact of Different Pesticides on Spider Species of Four Families
}

\author{
M. F. R. Mahmoud ; A. A. R. Rahil ${ }^{*}$ and M. S. A. Mohammad \\ "Plant Protection Dept. Faculty of Agric. Fayoum Univ., Fayoum, Egypt. \\ ${ }^{* *}$ Plant Protection Institute, Agricultural Research Center, Fayoum, Egypt.
}

\begin{abstract}
Fifteen species in 12 genera belong to four families were collected from tomato fields in L/-Fayoum governorate in 2006 and 2007 (July-Nov.). Collecting spiders started two weeks after the first acaricidal application and continued for ten weeks. Three different methods were used for collecting spiders i.e., sweeping net, direct count and pitfall traps. Challenger $\mathbb{R} 36 \%$ SC (Chlorofenapyr), Lambda $\widehat{\mathbb{R}} 5 \%$ SP (Pyrethroid), Selecron ${ }^{\circledR} 72 \%$ EC (Organophosphate) and successive applications of ten pesticides recommended for use against tomato pests caused highly significant reduction in spider populations. In 2006 season Lambda $\mathbb{R}$ treatment caused the highest significant reduction in the spider population $64 \%$ while, Selecron $\mathbb{B}$ enhanced the lowest reduction, 51\%. On the other hand in 2007 Challenger $\circledast$ treatment caused the highest reduction $65 \%$ while, Selecron ${ }^{\circledR}$ was the lowest one $57 \%$.
\end{abstract}

Key Words: True spiders, Tomato, Control, Challenger $\mathbb{R}$, Selecron $(\mathbb{B}$, Lambda $(\mathbb{B})$.

\section{INTRODUCTION}

Spiders are found almost everywhere. The number of individuals may reach 2,200,000 per acre in a grass field (Kaston and Kaston, 1953). Acephate, Propaphos, and the growth regulator Buprofezin were highly selective to the spiders. Although topical application of Buprofezin (Fenobucarb) and Cypermethrin inhibited the survival, growth and fecundity of Znilaparvata lugens (Stal.), Acephate and Propaphos materials reduced the growth and predation of the spider (Thang et al., 1987). Dimecron (Phosphamidon 85\% E.C.) and Parataf (Methylparathion 50\% E.C.) were used against five spider species. Toxicity of Dimecron was the highest (Mansour and Nentwig 1988, Thomas et al. 1990, Everts et al. 1991 and Shunmugavelu and Palanicham (1991). The density of hunting spiders was higher than that of web builders in the period after insecticide application . The activity of the hunters played an important role in population rebuilding (Lee et al., 1993). Pyrethroids sprayed on adults in webs was more effective than sprayed on sitting or walking spiders on the soil surface. In all tests, males were more susceptible than females, and this was related to body weight (Dinter and Poehling, 1995). Broadspectrum organophosphates were highly toxic to spiders. Dimethoate sprays resulted in 100\% mortality to the lycosid Trochosa ruricola (DeGeer) (Birnie el al., 1998). The organophosphate. Methyl Parathion and the pyrethroid Cypermethrin were highly toxic to spiders, genus Erigone (Linyphiidae), while the carbamate Pirimicarb was almost harmless (Huusela-Veistola 1998). The wolf spider, Paradosa pseudoannulata was highly tolerant to botanical insecticides such as Neem-based chemicals (Markandeya and Divakar, 1999). Spiders are generally more tolerant to organophosphates and carbamates than to pyrethroids, organochlorines, and other acaricides (Tanaka ef al., 2000). The acaricides, Vertimec 1.8\% E.C., Ortus 5\% S.C. and Cascade 10 $\%$ D.C. were harmful to spider causing $85.6 \%$, $84.8 \%$ and $76.6 \%$, reduction respectively, while Challenger $36 \%$ S.C. was moderately effective causing 70.6\% reduction (Sallam, 2002). Pilarmate was the highest toxic followed by Actacron and Admiral (Rahil 2006). The present study aimed to evaluate the impact of four pesticides treatments on the spider assemblage in tomato farms in L1-Fayoum Governorate.

\section{MATERIALS AND METHODS}

Seedlings of tomato, Lycopersicom esculentum Mill, Super Jackal variety, were transplanted in July 2006 and 2007 in an area of $1 / 4$ feddan divided into 20 equal plots 8x6 meter each, at Ebshaway district, El-Fayoum Governorate. Each plot contained 8 rows of which two rows were left unplanted between plots to avoid contamination. All usual agricultural practices, except routine pest control. were followed. In a randomized block design 5 treatments $\times 4$ plots were employed to evaluate the effect of 3 pesticides separately, (i.e., Challenger ${ }^{\circledR} 36 \%$ SC. Lambda ${ }^{\circledR}$ $5 \% \mathrm{SP}$ and Selecron $\mathbb{R} \quad 72 \%$ EC tested at the recommended rates, 50, 200 and $250 \mathrm{ml} / 100$ liter water, respectively. The $4^{\text {th }}$ treatment included 10 pesticides, Table 1, listed in order of the ir application, one pesticide/spray. This order in Table (1) was chosen according to the period of activity against different pests that usually infest tomato plants including mainly white flies, leafminers. mites, and other pests.

Spraying was carried out weekly for 10 weeks 
Table (1): Pesticides, rates and order of spray in treatments

\begin{tabular}{llcc}
\hline \multicolumn{1}{c}{ Trade name } & Active ingredient & rate $/ 100$ liter & Type \\
\hline Mospilan $(20 \% \mathrm{SP})$ & Acetamiprid & $25 \mathrm{gm}$ & Insecticide \\
Lambda $(5 \% \mathrm{SP})$ & Piperonyl butoxide & $200 \mathrm{ml}$ & Insecticide \\
Selecron $(72 \% \mathrm{EC})$ & Profenofos & $250 \mathrm{ml}$ & Insecticide \\
Challenger $(36 \% \mathrm{SC})$ & Chlorfenapyr & $50 \mathrm{ml}$ & Acaricide \\
Ortus $(5 \% \mathrm{EC})$ & Fenpyroximate & $50 \mathrm{ml}$ & Acaricide \\
Transact $(1.8 \% \mathrm{EC})$ & Abamctine & $50 \mathrm{ml}$ & Acaricide \\
Dithane $(80 \% \mathrm{WP})$ & Mancozip & $250 \mathrm{gm}$ & Fungicide \\
Abalone $(1.8 \% \mathrm{EC})$ & Abamctine & $50 \mathrm{ml}$ & Acaricide \\
Killmite $(1.8 \% \mathrm{EC})$ & Abamctine & $40 \mathrm{ml}$ & Acaricide \\
Endo $(50 \% \mathrm{EC})$ & Profenofos & $250 \mathrm{ml}$ & Insecticide \\
\hline
\end{tabular}

starting 10 days after transplantation. Biweekly, collections and counts of true spiders started two weeks after the first application and continued for 10 weeks. Each count included 100 double strokes of a sweeping net besides direct count of spiders on 20 randomly selected plants. Also 10 pitfall traps per treatment were employed. These traps were placed for 24 hours prior to the date of count. The collected spiders were immediately preserved in $70 \%$ alcohol in glass vials $(15 \mathrm{ml})$ for estimation. Identification of the collected spiders was carried out according to Denis 1947, Levi and Levi 1968, Kaston 1978, Levy and Amitai 1982 and Breene et al., 1993.

\section{Statistical analysis:}

ANOVA test was used to analyze the differences between the effect of pesticide treatments on spider population.

\section{RESULTS AND DISCUSSION}

\section{I) Spiders species in untreated plots in tomato field: \\ Season 2006:}

As shown in Table (2), 15 species of 12 genera belong to four families were found. Theridiid species had the largest collected numbers/season, followed by Lycosidae, Dictynidae and Philodromidae. The three dominant species were $D$. segregata, $T$. formicinus and An. aulicus. The populations of the theridiid, A. tepidariorum, the lycosids Pi. piratica and P. milvina were recorded in moderate numbers. Two species namely; T. aurantiaca and Th. murarium were found in low population. On the other hand, five species were rarely noted.

\section{Season 2007:}

As shown in Table (2) 15 species of 12 genera belong to four families were found. The largest collected numbers/season belong to Dictynidae followed by Theridiidae, Lycosidae and Philodromidae. Three species D. segregata, T. formicinus and An. aulicus were the most dominant . The Theridiid, A. tepidariorum and the Lycosid Pi. piratica were found in moderate numbers; while four species namely; $P$. milvina, $L$. helluo, S. avida and T. aurantiaca were found in low numbers. On the other hand, four species were rare. Results revealed that spiders were found allover each season as indicated by periodic regular collections methods.

\section{Spider species in plots treated with ten successive applications of pesticides in tomato field:}

Season 2006:

As shown in Table (3), 11 species of nine genera belong to four families were found. The largest collected numbers belong to Lycosidae while members of three families; Theridiidae, Dictynidae and Philodromidae were found in moderate numbers. Four species D. segregata, T. formicinus, Pi. piratica and An. aulicus were found in moderate numbers while five species, $A$. tepidariorum, $L$. helluo, P. milvina, L. gulosa and T. curantiaca were found in low numbers. On the other hand, the two species $L$. antelucana (Lycosidae) and T. murarium (Theridiidae) were rarely noted.

\section{Season 2007:}

As shown in Table (3), ten species of eight genera belong to four families were found. The largest collected numbers belong to Lycosidae and Dictynidae, followed by Theridiidae and Philodromidae, which were recorded in moderate numbers. The species $D$. segregata was dominant, while the two species; $T$. formicin $u$ and $P$. piratica were found in moderate numbers. Three species, An. aulicus, A. tepidariorum and P. milvina were found in low numbers. On the other hand, the four species $T$. aurantiaca, L. helluo, L. gulosa, L. antelucana (Lycosidae) were rarely noted. Generally, four species were found in untreated plots, while not noted in treated fields. The treatment with the successive applications of ten pesticides caused highly significant reduction in spider populations $56^{\circ} \%$ and $62 \%$ during 2006 and 2007 seasons, respectively. 
Table (2): Population and relative abundance of spiders families and species collected from untreated tomato fields in 2006 and 2007 ( July - Nor .) in El-Fayoum Governorate

\begin{tabular}{|c|c|c|c|c|c|}
\hline \multirow[b]{2}{*}{ Family } & \multirow[b]{2}{*}{ Species } & \multicolumn{2}{|c|}{2006 Season } & \multicolumn{2}{|c|}{2007 Season } \\
\hline & & $\begin{array}{c}\text { Total/ } \\
\text { Season } \\
\end{array}$ & $\begin{array}{c}\% \text { Species \& } \\
\text { Families } \\
\end{array}$ & $\begin{array}{l}\text { Total } \\
\text { Season } \\
\end{array}$ & $\begin{array}{c}\%(\text { Species \& } \\
\text { Families }\end{array}$ \\
\hline Dictynidae Cambirage & Dictina segregate Gertsch \& Mulaik & 121.0 & 24.5 & 164.0 & 31.4 \\
\hline \multirow{10}{*}{ Lycosidae Sundevall } & Arctosa rubicurde (Keyserling) & 00.0 & 00.0 & 02.0 & 0.003 \\
\hline & Lycosa antelucana Montgomery & 06.0 & 1.0 & 03.0 & 0.01 \\
\hline & L. gulosa Walckenaer & 10.0 & 2.0 & 08.0 & 0.02 \\
\hline & L. hellıo Walckenaer & 08.0 & 2.0 & 19.0 & 3.6 \\
\hline & Paradosa disticta (Blackwell) & 00.0 & 00.0 & 04.0 & 0.02 \\
\hline & P. milvina (Hentz) & 33.0 & 6.7 & 26.0 & 4.9 \\
\hline & Pirata piratica (Clerck) & 39.0 & 7.9 & 33.0 & 6.3 \\
\hline & Schizocosa avida (Walckenaer) & 10.0 & 2.0 & $17.0^{\circ}$ & 3.3 \\
\hline & Trabea aurantiaca (Emerton) & 20.0 & 4.0 & 16.0 & 3.3 \\
\hline & Sub total & 126.0 & 25.6 & 128.0 & 24.5 \\
\hline Philodromidae Thorel & Tanatus formicinus (Clerck) & 104.0 & 21.1 & 102.0 & 19.5 \\
\hline \multirow[t]{5}{*}{ Theridiidae Sundevall } & Anelosimus aulicus (Koch) & 80.0 & 16.3 & 83.0 & 15.9 \\
\hline & Achaearanea tepidariorum (Koch) & 46.0 & 9.3 & 47.0 & 9.0 \\
\hline & Crustulina altera Gertsch \& Archer & 01.0 & 0.2 & 00.0 & 00.0 \\
\hline & Therdion murarium Emerton & 14.0 & 2.8 & 08.0 & 0.02 \\
\hline & Sub total & 141.0 & 28.6 & 138.0 & 26.4 \\
\hline Total/season & & 492.0 & & 522.0 & \\
\hline
\end{tabular}

Table (3): Population and relative abundance of șiútiois fámilies and species coiliected from tomato fields treated with successive applications of ten pesticides in 2006 and 2007 (July - Nov.) in El-Fayoum Governorate

\begin{tabular}{|c|c|c|c|c|c|}
\hline \multirow[b]{2}{*}{ Family } & \multirow[b]{2}{*}{ Species } & \multicolumn{2}{|c|}{2006 Season } & \multicolumn{2}{|c|}{2007 Season } \\
\hline & & $\begin{array}{l}\text { Total / } \\
\text { Season }\end{array}$ & $\begin{array}{c}\text { \% Species \& } \\
\text { Families }\end{array}$ & $\begin{array}{l}\text { Total / } \\
\text { Season }\end{array}$ & $\begin{array}{l}\text { \% Species } \\
\& \text { Families }\end{array}$ \\
\hline Dictynidae & D. segregata & 43.0 & 19.0 & 68.0 & 31.5 \\
\hline \multirow{7}{*}{ Lycosidae } & L. antelucana & 08.0 & 3.5 & 04.0 & 1.9 \\
\hline & L. gulosa & 13.0 & 6.0 & 07.0 & 3.2 \\
\hline & L. helluo & 20.0 & 8.7 & 09.0 & 4.2 \\
\hline & P. milvina & 14.0 & 6.0 & 12.0 & 5.6 \\
\hline & Pi. piratica & 33.0 & 14.3 & 33.0 & 15.3 \\
\hline & T. aurantiaca & 11.0 & 4.8 & 04.0 & 1.9 \\
\hline & Sub total & 99.0 & 42.9 & 69.0 & 29.9 \\
\hline Philodromidae & T. formicinus & 34.0 & 14.7 & 38.0 & 17.6 \\
\hline \multirow[t]{4}{*}{ Theridiidae } & An. aulicus & 31.0 & 13.4 & 29.0 & 13.4 \\
\hline & A. tepidariorum & 21.0 & 9.1 & 12.0 & 5.6 \\
\hline & T. murarium & 03.0 & 1.3 & 00.0 & 00.0 \\
\hline & Sub total & 55.0 & 23.8 & 41.0 & $18 . \overline{9}$ \\
\hline Total/season & & 231.0 & & 216.0 & \\
\hline
\end{tabular}

\section{III-Families and species in plots treated with Challenger $\mathbb{B}$}

Season 2006:

As shown in Table (4), 11 species of ten genera belong to four families were found. The largest numbers collected during the season belong to Lycosidae and Dictynidae. Individualis of families; Theridiidae and Philodromidae were found in moderate numbers. spectively. The number of $D$. segregata was the highest number, while $T$. formicinus and $A$. aulicus were found in moderate numbers. On the other hand, $P$. piratica. L. hethen and $A$. tepidariorum were found in low numbers. while 5 species were rarely recorded.

\section{Season 2007:}

As shown in Table (4), 13 species of nine genera belong to four families were found. The largest numbers collected during the season belong to Lycosidae. Members of Dictynidae and Theridiidae were found in moderate numbers, Philodromid spiders were found in low number. Three species namely; $D$. segregata, $P$. piratica and A. aulicus were found in moderate numbers. Two species namely: $T$. formicints and $P$. milvina were found in low numbers. On the other hand 5 species were rare. Generally: species namely: A. ribicurde 
(Lycosidae) and, C. altera (Theridiidae) were found in untreated plots and not found in Challengar treatment. Challenger $(B)$ treatment caused highly significant reduction in the spider population averaged of $60 \%$ and $65 \%$ during 2006 and 2007 , respectively. Sallam (2002) found that the acaricides Vertimec ${ }^{\circledR} \quad 1.8 \% \quad$ E.C., Ortus ${ }^{\circledR} \quad 5 \% \quad$ S.C. and Cascade ${ }^{\circledR} \quad 10 \%$ D.C. were harmful; while Challenger ${ }^{\circledR} 36 \%$ S.C. was moderately effective .

\section{Spider species recorded in plots treated with Lambda $\left.{ }^{(}\right)$: \\ Season 2006:}

As shown in Table (5), ten species of 10 genera belong to four families were found. The largest numbers of collected sphders belong to Dictynidae (64.0 individuals), representing $(33.3 \%)$ of the total population in the field. Members of families Theridiidae and Lycosidae were found in moderate numbers. Philodromid spiders were found in low numbers. D. segregata was predominant followed by $A$. aulicus which was found in moderate number. Three species namely; $T$. formicinus, $P$. piratica and $A$. tepidariorum were found in low numbers. On the other side, the four species, namely; P. milvina, $T$. aurantiaca, L. gulosa, S. avida (Lycosidae) and T.murarium (Theridiidae) were rarely noted.

\section{Season 2007:}

As shown in Table (5), 12 species of nine genera belong to four families were found. The largest numbers of collected spiders during the season belonged to Lycosidae and Theridiidae. Members of families Dictynidae and Philodromidae were found in moderate numbers. The four species, $D$. segregata, $A$. aulicus, $P$. piratica and $T$. formicinus were found in moderate numbers, while the three species, A. tepidariorum, $P$. milvina and $T$. aurantiaca were found in low numbers. On the other hand, 5 species were rare. The two species; $A$. rubicurde, and $C$. altera were found in untreated plots, but were not recorded in Lambda® treatment. Lambda ${ }^{\circledR}$ treatment caused highly significant reduction in the spider populations. Dinter and Poehling (1995) tested the side effects of pyrethroids insecticides (Fenvalerate and Lambda $\mathbb{R}$ cyhalothrin(B) on two erigonid spider species. Pyrethroids sprayed on adults in webs had stronger effects than pyrethroids sprayed on sitting or walking spiders on the soil surface. Residual contamination caused greater mortality of spiders

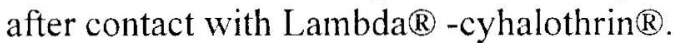

\section{V-Spider species recorded in plots treated with Selecron ():}

Season 2006:

As shown in Table (6), 11 species of nine genera belong to four families were recorded. The largest collected numbers belong to Dictynidae, Theridiidae and Lycosidae. Philodromid spiders were found in moderate number. D. segregata was predominant, followed by $A$. aulicus and $T$. formicinus which were found in moderate numbers. The three species; $A$. tepidariorum, L. helluo an $P$. piratica were found in low numbers. On the other hand, 5 species were rare.

\section{Season 2007:}

As shown in Table (6), 13 species of 10 genera belong to four families were recorded. The largest collected numbers belong to Theridiidae. Members of Dictynidae and Philodromidae were found in moderate numbers represented by three species; $D$. segregata, $A$. aulicus and $T$. formicinus while the three species; $P$. piratica, $A$. tepidariorum and $P$. milvina were found in low numbers. On the other hand, seven species were rarely noted. The highest number of species and spiders population were recorded in plots treated with Selecron compared to other pesticides. Generally, the two species namely, A. rubicurde (Lycosidae) and C. altera (Theridiidae) were found in untreated plots and not found in. Selecron $\mathbb{R}$ treatment caused highly significant reduction in the spider populations. Tanaka et al. (2000) found that the spiders generally are more tolerant to organophosphates and carbamates than to pyrethroids, organochlorines, and various acaricides.

\section{VI ) Reduction percentage of spider population as a result of pesticides treatments: \\ Season 2006:}

The reduction percentage of population density differed according to type of pesticide and spider behavior (Table, 7). During this study, family Dictynidae which belong to web building spiders recorded reduction percentage of 49.6, 47.1, 36.4

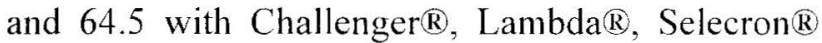
and sequnce ten pesticides, during 2006 season respectively, compared with control. Family Lycosidae which belong to hunting spiders recorded reduction of $45.2, \quad 65.0,50.8$ and $21.4 \%$, respectively. Family Philodromidae which belong to hunting spiders recorded reduction of 67.0, 73.1, 64.4 and $67.3 \%$ in the same treatments, respectively, while family Theridiidae which belong to web building spiders recorded reduction of $67.4,60.3$, 55.3 and $60.9 \%$.

\section{Season 2007:}

As shown in Tale (7), family Dictynidae recorded reduction of $72.6,67.7,64.6$ and 58.5 with Challenger $(\mathbb{B}, \quad$ Lambda $\overline{\mathbb{R}}$. Selecron $\mathbb{Q}$ and ten successive pesticides. during 2007 season respectively. Family Lycosidae recorded reduction of $37.5,38.3,47.7$ and $46.1 \%$, respectively. Reduction of family Philodromidae was $72.5,67.6$, 59.8 and $62.7 \%$. respectively and reduction of family Theridiidae was 68.1 .52 .5 .49 .3 and $70.3 \%$, respectively. Total of reduction percentage of four 
Table (5): Population and relative abundance of spiders families and species collected from tomato fields treated with Lambda in 2006 and $200^{-}$( Jul - Nov.) in El-Fayoum Governorate

\begin{tabular}{|c|c|c|c|c|c|}
\hline \multirow[b]{2}{*}{ Family } & \multirow[b]{2}{*}{ Species } & \multicolumn{2}{|c|}{2006 Season } & \multicolumn{2}{|c|}{2007 Season } \\
\hline & & Total Season & ${ }_{0}{ }_{0}$ Species \& Families & Total/Season & $\%$ Species \& Families \\
\hline Dictynidae & D. segregata & $6+0$ & 33.3 & 53.0 & 22.8 \\
\hline \multirow[t]{9}{*}{ Lycosidae } & L. antelucana & 00.0 & 00.0 & 05.0 & 2.2 \\
\hline & L. gulosa & 03.0 & 1.6 & 06.0 & 2.6 \\
\hline & L. helluo & 00.0 & 00.0 & 01.0 & 0.4 \\
\hline & P. disticta & 00.0 & 00.0 & 07.0 & 3.0 \\
\hline & Pi. milvina & 06.0 & 3.1 & 13.0 & 5.6 \\
\hline & P. piratica & 25.0 & 13.0 & 36.0 & 15.5 \\
\hline & S. avida & 05.0 & 2.6 & 00.0 & 00.0 \\
\hline & T. aurantiaca & 05.0 & 2.6 & 11.0 & 4.7 \\
\hline & Sub total & 44.0 & 22.9 & 79.0 & 34.1 \\
\hline Philodromidae & T. formicinus & 28.0 & 14.6 & 33.0 & 14.2 \\
\hline \multirow[t]{4}{*}{ Theridiidae } & An . anlicus & 31.0 & 16.1 & 47.0 & 20.3 \\
\hline & A tepidariorum & 18.0 & 9.4 & 17.0 & 7.3 \\
\hline & T. murarium & 07.0 & 3.6 & 03.0 & 1.2 \\
\hline & Sub total & 56.0 & 29.2 & 67.0 & 28.9 \\
\hline Total/season & & 192.0 & & 232.0 & \\
\hline
\end{tabular}

Categories: $\mathrm{R} \leq 10 \quad$ spiders for season $\quad \mathrm{L}=11-30 \quad \mathrm{M}=31-60 \quad \mathrm{H}=>60$

Table (6): Population and relative abundance of spiders collected from tomato fields treated with Selecron ${ }^{\circledR}$ in 2006 and 2007 (July - Nov.) in El-Fayoum Governorate

\begin{tabular}{|c|c|c|c|c|c|}
\hline \multirow[b]{2}{*}{ Family } & \multirow[b]{2}{*}{ Species } & \multicolumn{2}{|c|}{2006 Season } & \multicolumn{2}{|c|}{2007 Season } \\
\hline & & Total / Season & \% Species \& Families & Total/Season & \% Species \& Families \\
\hline Dictynidae & D. segregata & 77.0 & 32.2 & 58.0 & 24.6 \\
\hline \multirow{9}{*}{ Lycosidae } & L. antelicana & 04.0 & 1.6 & 02.0 & 0.8 \\
\hline & L. gulosa & 06.0 & 2.5 & 05.0 & 2.1 \\
\hline & L. helluo & 19.0 & 7.9 & 07.0 & 2.9 \\
\hline & P. disticta & 00.0 & 0.0 & 07.0 & 2.9 \\
\hline & P. milvina & 10.0 & 4.1 & 17.0 & 7.2 \\
\hline & Pi. piratica & 18.0 & 7.5 & 19.0 & 8.1 \\
\hline & S. avida & 00.0 & 0.0 & 06.0 & 2.5 \\
\hline & T. aurantiaca & 05.0 & 2.0 & 04.0 & 1.6 \\
\hline & Sub total & 62.0 & 25.9 & 67.0 & 28.3 \\
\hline Philodromidae & T. formicinus & 37.0 & 15.4 & 41.0 & 17.3 \\
\hline \multirow[t]{4}{*}{ Theridiidae } & A n. aulicus & 38.0 & 15.8 & 47.0 & 19.9 \\
\hline & A.tepidariorum & 23.0 & 9.6 & 18.0 & 7.6 \\
\hline & T. murarium & 02.0 & 0.8 & 05.0 & 2.1 \\
\hline & Sub total & 63.0 & 26.3 & 70.0 & 29.6 \\
\hline Total / season & & 239.0 & & 236.0 & \\
\hline
\end{tabular}

Table (7): Reduction percentage of spider populations as a result of pesticides treatments

\begin{tabular}{|c|c|c|c|c|c|c|c|c|c|c|}
\hline \multirow{3}{*}{$\begin{array}{l}\text { Pesticides } \\
\text { Family }\end{array}$} & \multicolumn{6}{|c|}{ Single Pesticides } & \multirow{2}{*}{\multicolumn{2}{|c|}{$\begin{array}{c}\text { Ten successive } \\
\text { pesticides }\end{array}$}} & \multirow{2}{*}{\multicolumn{2}{|c|}{ Control }} \\
\hline & \multicolumn{2}{|c|}{ Challenger $(\mathbb{R})$} & \multicolumn{2}{|c|}{ Lambda $\mathrm{R}$} & \multicolumn{2}{|c|}{ Sclecron $\mathbb{R}$} & & & & \\
\hline & 2006 & 2007 & 2006 & 2007 & 2006 & 2007 & 2006 & 2007 & 2006 & 2007 \\
\hline Dictynidac & 61.0 & 45.0 & 64.0 & 53.0 & 77.0 & 58.0 & 43.0 & 68.0 & 121.0 & 164.0 \\
\hline$\%$ reduction & 49.6 & 72.6 & 47.1 & 67.7 & 36.4 & 64.6 & 64.5 & 58.5 & & \\
\hline Lycosidae & 69.0 & 80.0 & 44.0 & 79.0 & 62.0 & 67.0 & 99.0 & 69.0 & 126.0 & 128.0 \\
\hline$\%$ reduction & 45.2 & 37.5 & 65.0 & 38.3 & 50.8 & 47.7 & 21.4 & 46.1 & & \\
\hline Philodromidae & 40.0 & 28.0 & 28.0 & 33.0 & 37.0 & 41.0 & 34.0 & 38.0 & 104.0 & 102.0 \\
\hline$\%$ reduction & 60.2 & 72.5 & 73.1 & 67.6 & 64.4 & 59.8 & 67.3 & 62.7 & & \\
\hline Theridiidac & 46.0 & 44.0 & 56.0 & 67.0 & 63.0 & 70.0 & 55.0 & 41.0 & 141.0 & 138.0 \\
\hline$\%$ reduction & 67.4 & 68.1 & 60.3 & 52.5 & 55.3 & 49.3 & 60.9 & 70.3 & & \\
\hline Total & 216.0 & 197.0 & 192.0 & 232.0 & 239.0 & 236.0 & 231.0 & 216.0 & 492.0 & 532.0 \\
\hline Mean \pm SE & $54.0 \pm 6.7$ & $49.3 \pm 10.9$ & $48.0 \pm 7.8$ & $58.0 \pm 9.9$ & $59.8 \pm 8.3$ & $59.0 \pm 6.5$ & $57.8 \pm 14.4$ & $54.0 \pm 8.4$ & $123.0 \pm 7.6$ & $133.0 \pm 12.8$ \\
\hline$\%$ reduction & 56.1 & 62.9 & 60.9 & 56.4 & 51.4 & 55.6 & 53.0 & 59.4 & & \\
\hline Duncan test & $\mathrm{b}$ & & $\mathrm{b}$ & $\mathrm{B}$ & & B & $\mathrm{b}$ & $\mathrm{B}$ & $\mathrm{a}$ & A \\
\hline
\end{tabular}


families during 2006 season was 56.1, 60.9, 51.4 and $53.0 \%$ compared with $62.9,56.4,55.6$ and $59.4 \%$ respectively. Statistical analysis indicated that non significant differences occurred between the effect of all pesticides used during 2006 and during 2007, while highly significant differences occurred between control and other treatments during 2006 and during 2007. Generally, results indicated that, population of the spiders were influenced by all pesticides used.

\section{ACKNOWLEDGMENT}

Deep thanks are due to Dr. Marguerite Adly Rizk Professor of Agric. Zoology (Acarology), Plant Protection Research Institute, Agricultural Research Center for facilities and advice .

\section{REFERENCES}

Birnie, L.; Shaw, K.; Pye B. and Denholm, I. 1998. Concedrations with the use multiple dose bioassays for assessing pesticide effects on nontarget arthropods. In Proceedings, Brighton Crop Protection Conference. Pests and Diseases. 16-19 November, Brighton, UK. 291-296.

Breene, R. G.; Dean, D. A; Nyffeler, M. and Edwards, M. B. 1993. Biology, predation ecology, and significance of spiders in Texas cotton ecosystems with a key to the species. Dept. of Ent., Texas Univ., Coll. State., U.S.A.

Denis, J. F. Z. S. 1947. Results of the Armstrong college expedition to Siwa oasis (Libyan Desert) 1935. Bull. Soc. Fouad $1^{\text {st }}$ Entom., xxxl, (17):85 pp.

Dinter, A. and Poehling, H. M. 1995. Side-effect of the insecticides on tow Erigonid spider species. Entomol. Exp. Appl., 74 (2): 151-163.
Huusela-Veistola, E. 1998. Effects of perennial grass strips on spiders (Araneae) in cereal fields and impact on pesticide side-effects. J. Appl. Ent., 122:575.583.

Kaston, B. J. 1978. How to know the spiders. keys to common spider genera. W. C. Brown Co., Dubuque, Iowa, U.S.A., 272 pp.

Kaston, B. and Kaston, E.,1953. How to know the spiders. W. C. Brown Co., Dubuque, lowa, U.S.A., $220 \mathrm{pp}$.

Lee, H. P.; Kim, J. P. and Jun, J. R. 1993. Influences of the insecticidal application on the natural enemies and spider community. J. Indus. Tech. Grad. Sch. Dongguk Univ. 1: 295-307.

Levi, H. W. and Levi, L. R. 1968. Spider and their Kin. New York, 160 pp.

Levy, G. and Amitai, P. 1982 .The comb footed spider genera Theirdion, Achaearanea and Anelosimus of Israel (Araneae: Theridiidae), J. Zool . Lond., 196: 81-131.

Mansour, F. and Nentwig. W. 1988. Effect of agrochemical residues on four spider taxa, laboratory methods for pesticides test with webbuilding spiders. Phytoparasitica., 16 (4): 317 326.

Markandeya, V. and Divakar, B. J. 1999. Effect of a neem formulation on four bioagents. Plant Prot. Bulletin. 51:28-29.

Rahil, A. A. R. 2006. Impact of pesticides use on true spider population in tomato farms in Fayoum governorate. Fayoum J. Agric. Res. \& Dev., 20(1): 148-154.

Sallam,G. M., 2002. Studies on true spiders in Egypt. Ph. D. thesis, Fac. of Agric., Cairo Univ., $144 \mathrm{pp}$.

Shunmugavelu and Palanicham, M. S. 1991. Preliminary studay on the effect of insecticides on spiders, J. Ecobiol., 3 (3-4): 253-255. 